\section{IJ§ER}

ISSN: 2149-5939
International Journal of Social Sciences and Education Research

Online, http://dergipark.gov.tr/ijsser

Volume: 1(1), 2015

\title{
Intertextual relationships in Toni Morrison's The Bluest Eye
}

Bülent Cercis Tanrıtanır ${ }^{1}$

\author{
Kıvılcım Uzun²
}

Received Date: $01 / 01 / 2015$

Accepted Date: 01 / 02 / 2015

\begin{abstract}
Toni Morrison is mostly known for frequently bringing up the problems of African-American people living in the US and of the black women in particular and social issues like racism, discrimination, feminism and male domination. She is also famous for revealing starkly the lives of African American society within dominant American culture from past to present. Morrison strengthens her fiction by establishing a close relationship between her stories and various texts as a significant characteristic feature of the postmodern period that she also belongs to. This close relationship can obviously be seen in The Bluest Eye which is the first novel of Morrison. In The Bluest Eye, she shows how the incidents that are the symbols of happiness for white society affect the African-American people by referring to a famous child story Dick-and-Jane that is well-known for American society. Furthermore, entitling the chapters of the novel as a season, she negates the features which people associates with seasons for African people living in the US. This study aims to examine the intertextual relationships in The Bluest Eye.
\end{abstract}

Keywords: Intertextuality, Postmodernism, Toni Morrison, African-American society

\section{Introduction}

Being the very first and maybe the most remarkable novel of Toni Morrison, The Bluest Eye tells the meaning of being a black young girl in a society in which the white culture dominance is felt over blacks and is blessed by both capitalist system and society itself. Using a literal language far from any emotional abuse or exaggeration, the writer shapes the whole events around two families living in Ohio, MacTeers and Breedloves. In particular, the center character is Pecola who is frequently called as "black" and "ugly" or both at once by other kids and even her family. Because she wants to have a happier life and lovely family, she prays everyday in order to have blue eyes as it's shown in the press or commercials as the ideal beauty. In her Nobel-winning novel, Morrison questions the system and the society which makes a young black girl believe her life would be better and change forever if she has blue eyes and finally causes her stepping into madness after being raped by her father.

Within this content, it won't be wrong to claim that the novel consists of two main units: the prefatory unit and the story. The prefatory unit also has two different parts first one of which resembles to one of the widely known children's story, in other words Dick-and-Jane story which is repeated three times at the very beginning of the novel. Another part of the prefatory units can be assumed as a kind of introduction part uttered by the first person narrator, Claudia who is another black girl living in the same town with Pecola. Another unit of the novel is the story part which is divided into four main sections named as the four seasons of the years. Apart from this type of division, the story has been divided into minor chapters and each of which is headlined as one sentence retrieved from the children's story given at the very beginning of the prefatory unit.

\footnotetext{
${ }^{1}$ Assoc. Prof. Dr., University of Yüzüncü Y11, Department of English Language and Literature, Van/TURKEY, bctanritanir@gmail.com

${ }^{2}$ Lecturer, School of Foreign Languages, Van/TURKEY, kivilcim.iskra@gmail.com 
Tanritanır, B.C. \& Uzun, K. (2015). Intertextual relationships in Toni Morrison's The Bluest Eye. International Journal of Social Sciences and Education Research, 1 (1), 156-162.

Of course, none of these headlines or division style is coincidental; on the contrary, each one has an ironic meaning and logical sequence when they are analyzed intertextually. As counted as one of the post-modernist writers, Toni Morrison's most noticeable work, The Bluest Eye is in the need of being analyzed intertextually. Because postmodernism is known as a movement which represents the concept of the universe in which individual works are not dealt with in isolation, in the study of literature, the focus is much more on intertextual relationship between visual images or the texts written. Intertextuality is defined as referring to the ways that the texts whether written or visual, are interpreted one in the light of another to produce new meanings (Walker \& Chaplin, 1997, p.142). The postmodern writers mostly use fairy-tales to refer in their original text; however, it's also possible to encounter these kinds of references in different ways. In Morrison's The Bluest Eye, neither Dick-and-Jane story nor other kinds of divisions of the novel has been written accidently and Morrison has put a logical sequence between different texts of the novel. In this paper, we aim to search for this meaning and logic underlying this mechanism of intertextual allusion among the prefatory unit, the headlines of the novel and the main story.

\section{Dick-and-Jane Story and the Prolepsis}

As mentioned above, the first part of the novel called as prefatory unit has two components one of which is the part in which there is a kind of children's story typed as three different versions and the other one of which is the part in which Claudia sums up the whole story in one page. Firstly, it will be appropriate to concentrate on the opening part of the novel which starts with the story below:

Here is the house. It is green and white. It has a red door. It is very pretty. Here is the family. Mother, Father, Dick, and Jane live in the green-and-white house. They are very happy. See Jane. She has a red dress. She wants to play. Who will play with Jane? See the cat. It goes meow-meow. Come and play. Come play with Jane. The kitten will not play. See Mother. Mother is very nice. Mother, will you play with Jane? Mother laughs. Laugh, Mother, laugh. See Father. He is big and strong. Father, will you play with Jane? Father is smiling. Smile, Father, smile. See the dog. Bowwow goes the dog. Do you want to play with Jane? See the dog run. Run, dog, run. Look, look. Here comes a friend. The friend will play with Jane. They will play a good game. Play, Jane, play. (Morrison, 2007, p. 4)

Being told in the story, Dick and Jane is the name of a children's book which teaches reading to children and was very popular in USA in 1940s. Apart from teaching to read, these Dick-andJane stories have many subliminal missions, such as giving the ideal portrait of American families and teaching children the cultural values like gender and familial roles. Furthermore, even though we are never told so, we assume that the physical appearance of Dick-and-Jane is also appropriate for the beauty standards of American society: blonde hairs, blue eyes, cute and red dresses etc. In this story, the family of Dick and Jane looks very happy and the whole family is appropriate for the standards. The mother is caretaker and the father is worker and they are always nice, caring and lovely. They also live with a kitten and a dog in their garden. Morrison has written a kind of these widely known children's stories at the beginning of her novel but she doesn't want us to think that the world of Dick-and-Jane is better. On the contrary, she is associated with the ugly and unhappy life of black people to the values of this standardized and idealized world of white culture. 
Tanritanır, B.C. \& Uzun, K. (2015). Intertextual relationships in Toni Morrison's The Bluest Eye. International Journal of Social Sciences and Education Research, 1 (1), 156-162.

After concentrating on the meaning of the text, it's necessary to focus on its writing style. This first version of the story given above is clear and straight and also written in standard English and its grammar and orthography are correct, which is crucial for a literary work. Moreover, the text is logically connected; first of all the beautiful house is described and then the family members are introduced. No one will have difficulty in understanding it in this way. With these qualities, it will be possible to say that the text is appropriate for the standard of the world-model. However, the second version of the same story is written differently;

Here is the house it is green and white it has a red door it is very pretty here is the family mother father dick and jane live in the green-and-white house they are very happy see jane she has a red dress she wants to play who will play with jane see the cat it goes meowmeow come and play come play with jane the kitten will not play see mother mother is very nice mother will you play with jane mother laughs laugh mother laugh see father he is big and strong father will you play with jane father is smiling smile father smile see the dog bowwow goes the dog do you want to play do you want to play with jane see the dog run run dog run look look here comes a friend the friend will play with jane they will play a good game play jane play (p. 4)

This time punctuation and capital letters are lost and even though it's still readable and comprehensible it is more informal and less correct than the former one. The sentences come after one another immediately without any punctuation marks separating them. Although it seems like it doesn't fit the standards of the ideal one and orthography, it is more intelligible than the last version of the same story:

Hereisthehouseitisgreenandwhiteithasareddooritisveryprettyhere-

isthefamilymotherfatherdickandjaneliveinthegreenandwhitehousetheyareveryhappyseejan eshehasareddressshewantstoplaywhowillplaywithjaneseethecatit-

goesmeowmeowcomeandplaycomeplaywithjanethekittenwillnotplayseemothermotherisve rynicemotherwillyouplaywithjanemotherlaughslaughmother-

laughseefatherheisbigandstrongfatherwillyouplaywithjanefaterissmilingsmILefathersmile seethedogbowwowgoesthedogdoyouwanttoplaydoyouwanttoplay-

withjaneseethedogrunrundogrunlooklookherecomesafriendthefriendwillplaywithjanethey willplayagoodgameplayjaneplay (p. 4)

In the last version of the story, the sentences overlap with each other and it isn't possible to understand the text easily. There aren't any orthographic rules, punctuation and spaces between the words. It no longer looks like a story but just a jumble of words. It is far away from being the standard model of a story and it's illegible and incomprehensible.

When questioning or analyzing why the writer has chosen to write an ideal American family story in different versions as a prefatory part of her novel, it's important to observe the content of the novel. As mentioned before, choosing Pecola as her protagonist Morrison presents a real black family life in USA in The Bluest Eye. So, her writing the Dick-and-Jane story in this way may have two different meanings. First of all, she may try to show us the very unnatural existence of this ideal family portrait in reality by giving examples from the fictionalized story in the novel for each character of the Dick-and-Jane story. The sequence beginning from the standard to the chaotic one may show us the nonsense and unreality in the story taught in schools to kids. Another 
Tanrıtanır, B.C. \& Uzun, K. (2015). Intertextual relationships in Toni Morrison's The Bluest Eye. International Journal of Social Sciences and Education Research, 1 (1), 156-162.

comment on this sequence of the three versions of the story is that they represent the three types of family in reality:

These three versions are symbolic of the lifestyles that the author explores in the novel either directly or by implication. The first is clearly that of the alien white world which impinges upon the lives of black children and their families while at the same time excluding them. The second is the lifestyle of the two black MacTeer children, Claudia and Frieda, shaped by poor but loving parents trying desperately to survive the poverty, the Northern cold and Northern style of racism they encounter in Ohio. The Breedloves' lives, however, are like the third- the distorted run-onversion of "Dick-and-Jane", and their child Pecola lives in a misshapen world which finally destroys her (Klotman, 1979, p. 123).

After reading the novel, it's clear for the reader that the family of Breedloves, Pauline, Cholly, Sammy and Pecola metaphorically correspond to the prototypical figures of Mother, Father, Dick and Jane (Kewes, 1992, p. 49). This comparison becomes even much clearer when analyzing the sentences retrieved from the original story and given to each particular chapters of the novel as headlines by Morrison. For example, the headline of the chapter describing the Breedloves's house is that: "HEREISTHEHOUSEITISGREENANDWHITITHASAREDDOORITISVERYPRETTYITISVERYPRETTYITISVERYPRETTYITISVERYPRETTYPRETTYPRETTYP (p. 33).”

The chapter introduced Breedloves as a family bears this headline: "HEREISTHEFAMILYMOTHERFATHERDICKANDJANETHEFAM-

ILYLIVEINTHEGREENANDWHITEHOUSETHEYAREVERYH (p. 39).” In each chapter, it's clearly seen that the characters and their lives don't resemble to the one in Dick-and-Jane story at all. In spite of the green and white house in the story, the poverty and ugliness dominate the house of Breedloves. Under the headline which is retrieved from the story as Jane herself, we read the story of Pecola who is denied love and understanding by both family and the society. Being an irony with their last names, the Breedloves don't show any love to their daughters and she encounters the rejection by society because she is black, in other words, she isn't blonde and blueeyed. When Jane is playing the kitten, because of a rude boy named Geraldine, Pecola witnesses the humiliation and the death of a cat which has blue eyes as she always wants for herself. However, it's not the only animal dead in the novel. Contrary to the happy dog which wants to play with children in Dick-and-Jane story, Pecola poisoned the dog unconsciously and also witnesses the death of it. On the other hand, Pecola's loveless mother, Pauline is matched with the nice mother of Jane and her father, Cholly who is alcoholic and careless corresponds the big and strong father in the story. In these chapters bearing the sentences related to the mother and the father lines, we read the life of Pauline which is full of disappointment and unhappiness and the chaotic childhood and youth of Cholly Breedlove. Maybe the most remarkable and important example of this intertextual meaning between the Dick-and-Jane story and the novel itself is the last chapter and its headline. Its headline is:

"LOOKLOOKHERECOMESAFRIENDTHEFRIENDWILLPLAYWITHJANETHEYWILLPLAYAGOODGAMEPLAYJANEPLAY (p. 193)." However, we read that Pecola has stepped into madness after being raped by his father for the second time. The friend who comes to play Jane is matched with Pecola's herself whom she allegedly talks to about her new blue eyes. 
Tanritanır, B.C. \& Uzun, K. (2015). Intertextual relationships in Toni Morrison's The Bluest Eye. International Journal of Social Sciences and Education Research, 1 (1), 156-162.

As shown, these examples from the novel, in each chapter she gives a headline from Dickand-Jane story, Morrison questions the given happy family portrait and aims to negate the ideal family story by giving examples from the real life of black families. When doing this, she puts an intertextual and logical chain and she matches each sentence of the Dick-and-Jane story to one character of Breedlove family or an event Pecola experienced. She tries to describe the real world in the back streets of America and reveals that the lives there don't resemble to the one in the story at all. In this way the standard model of the Dick-and-Jane story is questioned and negated in many ways. As it is suggested in the novel, the idealized norms, standards or values belong to the white world not to black people's lives. That's why it's assumed by many literary critiques that the most chaotic version of the beginning story represents the life of Breedlove family. Moreover, by choosing the sentences as headlines of the chapters, the writer uses the most chaotic and disorder version and writes the words nonsensically without any punctuation or space between them. It also implies the nonsense and traversable existence of the happy family portrait in the real world.

After Dick-and-Jane story, Morrison prefers to continue with a kind of introduction part to the novel narrated by Claudia who is the youngest daughter of MacTeer family. She talks about being raped of Pecola by her father and the death of her babies at the end. For all these happenings, she blames herself with all her innocent childish thoughts because the seeds which her sister and she dropped didn't grow and they believed that if they were grown, Pecola's baby would live:

It was a long time before my sister and I admitted to ourselves that no green was going to spring from our seeds. Once we knew, our guilt was relieved only by fights and mutual accusations about who was to blame. For years, I thought my sister was right: it was my fault. I had planted them too far down in the earth. It never occurred to either of us that the earth itself might have been unyielding. (p. 8)

This part which is counted as the second constituent of the prefatory part at the beginning of our paper is a narration strategy in which the natural order of a typical story is reversed and its result is known from the beginning. This strategy is called prolepsis and is defined as any narrative maneuver that consists of narrating or evoking in advance an event that will take place later (Genette, 1980, p. 40). The prolepsis gives the reader a kind of the summary of the story so it causes that we, as readers, give up considering what will happen next but instead, we concentrate on why or how they happen. At the end of the prolepsis part, the things Claudia says and finishes her quasi-summary is very important: "There is really nothing more to say-except why. But since why is difficult to handle, one must take refuge in how" (p. 7).

This summary given as prolepsis at the beginning of novel has clearly an intertextual relationship with the rest of the story and it isn't given coincidently by the writer. It's clear that, Morrison wants the reader to focus on not the content of the happenings but the reasons of it. Beginning from the end, she shifts her novel from narrative to descriptive (Kewes, 1992, p. 53). When describing, she doesn't use an exaggerated language, which gives the implication that she talks about the real life which is contrary to generally known stories of American family life.

\section{Four Seasons}

The tension between the natural and unnatural one which is given with the help of prefatory part and Dick-and-Jane story in particular is also suggested by the division of the novel into the four main sections. Each of these sections is names as one of the seasons of the years because as 
Tanritanır, B.C. \& Uzun, K. (2015). Intertextual relationships in Toni Morrison's The Bluest Eye. International Journal of Social Sciences and Education Research, 1 (1), 156-162.

we know, the seasons are associated with some values, images and meanings by people. Even though there is also an intertextual connection between the seasons and happenings, there isn't any parallelism; on the contrary, the things associated with particular seasons are negated by unnatural changes which take place in the fictional world (Kewes, 1992, p. 54).

First of all, the novel begins with autumn and the writer tells what is happening in Breedlove's life in this season. In autumn when most of animals naturally start building shelters to protect themselves from the harsh weather conditions in winter, we see the unnatural conditions happened at Breedloves' houses. They've become homeless because the father, Cholly sets their house on fire. Their daughter, Pecola starts to live with MacTeers and becomes friend with their two daughters, Claudia and Frieda. One of the most important events in this season is that Pecola begins menstruating when she lives with strangers and is deprived of family warmth and love. Contrary to controversial association of autumn which is known as the season of death of nature, Pecola becomes a woman who is capable of giving life to a baby. Winter is turned into a false spring by the "disrupter of seasons", Maureen Peal, who comes to be another agent increasing Pecola's humiliation and sense of worthlessness (Kewes, 1992, p. 54-55). In spite of being known as the seasons of silence and sleep, Maureen Peal breaks this silence and refreshes the humiliation and ugliness of Pecola: "By the time this winter had stiffened itself into hateful knot that nothing could loosen, something did loosen it, or rather someone. A someone who splintered the knot into silver threads that tangled us, netted us, made us long for the dull chafe of the previous boredom ( $\mathrm{p}$. 67)."

Known as the season of rebirth of nature and new life, spring brings Pecola only sorrow and pain. She is raped by her own father, Cholly in spring and becomes pregnant when she is only 12 years old. Claudia clearly tells what has happened in Pecola's life in spring which is the seed time by these lines in the prolepsis part of the novel: "We had dropped our seeds in our own little plot of black dirt just as Pecola's father had dropped his seeds in his own plot of black dirt (p. 8)." Finally, in the summer which can be considered as the season of fruition or the season of natural gifts given by nature to humanity, it has only one gift for Pecola: her madness. After all of the events she experienced, she has gone mad in summer. Giving the four seasons of the year as the main headlines of the story and telling the events experienced by the protagonist, Morrison negates and reverses the common beliefs and general judgment of society once again.

Apart from the negation of the common beliefs about American family life, the seasons also imply that this circle of black people life will be completely the same even if the seasons change. This cycle of desperate lives of them becomes just like a natural cycle as it is in the seasons of the year. Time moves back and forth for the characters, whose lives unfold against the natural but inexorable progression of the seasons (Klotman, 1979, p. 125). This type of division also indicates that the events described in The Bluest Eye have occurred before and will occur again in the lives of black people and suggests that there is notion that for black people there is no escape from the cycle of life that Breedloves and MacTeer live in.

\section{Conclusion}

Known to be frequently used method by postmodernist writers, intertextual relationship can be clearly observed in Toni Morrison's widely known work, The Bluest Eye. When analyzed intertextually, the story under the name of Dick-and-Jane which is given at the very beginning of the novel in which the children raising in a white and happy family are told is used by the writer 
Tanritanır, B.C. \& Uzun, K. (2015). Intertextual relationships in Toni Morrison's The Bluest Eye. International Journal of Social Sciences and Education Research, 1 (1), 156-162.

as an important device in order to describe the unhappiness and sorrow of the black children growing in a black and poor family in the back streets of USA and also to reveal that the stories told to children and the books given in schools don't reflect the reality but they conversely have unnatural contents and existence. This kind of intertextuality can be also implicitly seen between the minor chapters into which she divided her novel and the fictionalized story itself. By giving one sentence from the Dick-and-Jane story to these minor chapters, Morrison puts an intertextual relationship between her original story in which Pecola's sorrowful life has been told and the sentences retrieved from the Dick-and-Jane story. When reading the original fictionalized story, the reader can clearly and easily comprehend this relationship. With the prolepsis part added at the beginning of the novel, the writer presents what will happen at the end of the story and blocks the curiosity of the reader, which shows that she wants them to concentrate not on the question what but rather on how and why. By doing this, she aims to draw attention to the reality of the events she told and to the unnaturalness of the world which white culture is idealized and standardized. Also by dividing her novel which is told literally into four main sections named as one of the four seasons of the year, Morrison targets to negate the attributions associated with seasons by white and happy people and beliefs about the natural cycle and also to display how natural events are reversed in the life of black people. By establishing an intertextual relationship between the beliefs about seasons and the black people's lives told in the novel, she also reveals that this unnatural cycle in the black people's life was observable in the past and also will be repeated in future in the same way.

\section{References}

Bishop, J. (1993). Morrison's The Bluest Eye. Explicator, 51, 52-255.

Christian, B. (1986). Black Feminist Criticism: Perspectives on Black Women Writers. New York: Pergamon Press.

Dittmar, L. (1990). Will the Cycle be Unbroken? The Politics of Form in The Bluest Eye. Novel: A Forum on Fiction, 23, 132-157.

Genette, G. (1980). Narrative Discourse. New York: Ithaca Cornell University Press,

Gillan, J. (2002). Focusing on the Wrong Front: Historical Displacement, Maginot Line and the Bluest Eye. African American Review, 36, 283-296.

Kewes, P. (1992). Intratextual Text Interation and Cultural Reinterpretation in Toni Morrison's The Bluest Eye. Studia Anglica Posnaniensia, 24, 47-56.

Klotman, P. R. (1979). Dick-and-Jane and the Shirley Temple Sensibility in the Bluest Eye. Black American Literature Forum, 13, 123-125.

Lee, D. H., \& Evans, M. (Eds.). (1985). the Quest for Self: Triumph and Failure in the Works of Toni Morrison. London\&Sydney: Pluto Press.

Morrison, T. (2007). The Bluest Eye. New York: Vintage Books.

Walker, J. \& Chaplin, S. (1997). Visual Culture: An Introduction. Manchester: Manchester University Press. 